\title{
The modified smart city concept for Russian municipalities in the context of change management
}

\author{
O.O. Komarevtseva
}

Plekhanov Russian University of Economics, Moscow, Russia; komare_91@mail.ru

\begin{abstract}
Relevance. Outdated tools and instruments for development and governance prevent the effective use of data and digital platforms in Russian cities, thus creating obstacles for the implementation of smart new solutions. Moreover, the established system of smart city evaluation is 'overloaded' with indicators. For these reasons, the smart city concept is inadequate for today's reality of most Russian municipalities, making it difficult for them to meet the national goals for the digitalization of the country's economy. The relevance of this study is determined by the need to adjust the smart city concept for municipal economy in Russia and to propose a modified version of this concept. Research objective. This study aims at creating a modified smart city concept by changing evaluation criteria and using a simulation model of municipal economy. Results. The study found that the established smart city concept is not entirely suitable for implementation in Russian municipalities. The lack of adequate methodology of smart city evaluation impedes efficient economic development of municipalities. Data and methods. The study applies a simulation model of municipal economy, which is built by using simulation modelling methods and the Bass diffusion model. Conclusions. The proposed modifications of the smart city concept can provide a springboard for economic development of Russian municipalities to achieve the goals of national digital strategies.
\end{abstract}

\section{KEYWORDS}

municipal economy, smart city concept, change management, simulation, risk, digitalization

\section{FOR CITATION}

Komarevtseva, O.O. (2020) The modified smart city concept for Russian municipalities in the context of change management. R-economy, 6(4), 292-298. doi: 10.15826/recon.2020.6.4.026

\section{Упрощение концепции Smart City для экономики муниципального образования в контексте управления изменениями}

\section{О.О. Комаревцева}

Российский экономический университет им. Г.В. Плеханова, Москва, Российская Федераиия; kотате_91@таіl.ru

\begin{abstract}
АННОТАЦИЯ
Актуальность. Устаревшие инструменты для развития и управления не позволяют эффективно использовать данные и цифровые платформы в городах России, создавая препятствия для реализации новых умных решений. Более того, сложившаяся система оценки умного города «перегружена» показателями. По этим причинам концепция умного города неадекватна сегодняшним реалиям большинства российских муниципальных образований, что усложняет им достижение национальных целей по цифровизации экономики страны. Актуальность исследования определяется необходимостью корректировки концепции умного города для муниципальной экономики в России и предложения модифицированной версии этой концепции. Цель исследования. Цель исследования заключается в формировании упрощенной концепции Smart City, за счет изменения критериев оценки и применения имитационной модели функционирования экономики муниципального образования. Результат. Исследование показало, что устоявшаяся концепция умного города не совсем подходит для реализации в российских муниципальных образованиях. Отсутствие адекватной методологии оценки умного города препятствует эффективному экономическому развитию муниципалитетов. Данные и методы. В исследовании применяется имитационная модель экономики муниципального образования, построенная с использованием методов имитационного моделирования и диффузионной модели Басса. Выводы. Предлагаемые модификации концепции умного города могут стать трамплином для экономического развития муниципальных образований России и достижения целей национальных цифровых стратегий. (c) Komarevtseva, O.O., 2020
\end{abstract}

\section{КЛЮЧЕВЫЕ СЛОВА}

муниципальная экономика, концепция Smart City, управление изменениями, имитация, риск, цифровизация

\section{FOR CITATION}

Komarevtseva, O.O. (2020) The modified smart city concept for Russian municipalities in the context of change management. R-economy, 6(4), 292-298. doi: 10.15826/recon.2020.6.4.026 


\section{Introduction}

Outdated tools and instruments for development and governance prevent the effective use of data and digital platforms in Russian cities, thus creating obstacles for the implementation of smart new solutions. Moreover, the established system of smart city evaluation is 'overloaded' with indicators. For these reasons, the smart city concept is inadequate for today's reality of most Russian municipalities, making it difficult for them to meet the national goals for the digitalization of the country's economy. Therefore, it is necessary to adjust the established smart city concept to make it suitable for Russian cities.

The smart city is commonly understood as an urban area that uses different digital technologies and methods for data collection. Insights gained from such data about citizens, devices, buildings, etc. are then processed and analyzed to monitor and manage traffic and transportation systems, power plants, utilities, water supply networks, waste, crime detection information systems, schools, libraries, hospitals, and other community services (Anthopoulos et al., 2016).

The smart city concept integrates information and communication technologies (ICT) and various physical devices connected to the IoT network to optimize the efficiency of city operations and services and connect to citizens. This way city officials are able to interact directly with both community and city infrastructure and to monitor what is happening in the city and how the city is evolving. ICTs are used to enhance quality, performance and interactivity of urban services, to reduce costs and resource consumption and to increase contact between citizens and government (Chan et al., 2019). The smart city applications are developed to manage urban flows and allow for real-time responses. The smart city may therefore be more prepared to respond to challenges than the one with a simple "transactional" relationship with its citizens (Habib et al., 2020).

The purpose of this research is to propose a modified smart city concept by changing the assessment criteria and applying the simulation model of municipal economy. Our research objectives are as follows:

- to consider the key features of the smart city concept;

- to select indicators for assessing the modified city concept for municipal economy;
- to build a simulation model of municipal economy within the framework of the proposed modified smart city concept.

\section{Theoretical framework}

The smart city status cannot be assigned to all municipalities for a number of reasons. First, the high debt dependence and budget deficit of municipalities prevent their governments from implementing the smart city concept (Medvedev et al., 2015). To address this issue, it is necessary to enhance the innovative potential of municipalities. The smart city concept creates a technologically active urban environment and is based on the creation of an online platform (Barriga et al., 2016). Thus, the smart city concept introduces information and communication standards to improve the life of the population (Horejsi et al., 2020). However, for successful implementation of this concept, an adequate regulatory legal framework is required (Zhuhadar et al., 2017).

For the municipal level, statistical studies are carried out according to the given estimated parameters of smart-elements (Glebova et al., 2014). Most systems of smart city evaluation, however, are 'overloaded' with indicators and criteria (De Domenico et al., 2015), which unnecessarily complicates the process of evaluation. For example, Scornavacca et al. (2020) outline more than 15 criteria of a smart city. Another problem is the lack of statistical information necessary for smart city evaluation (Khatoun \& Zeadally, 2016). Official statistics fail to provide data on the indicators 'the level of citizens' involvement in city management' (Cao, Wang, 2011). Moreover, the existing evaluation systems can be rather subjective and there is no universal agreement among the research concerning the indicators and criteria to be applied. For example, Tan \& Taihagh (2020) choose as the key indicator 'the level of activity of Internet users' while Ishkineeva \& Akhmetova (2015), 'the level of civil initiatives on local issues'.

Finally, the models for the implementation of the smart city concept are not adapted to the characteristics of Russian municipalities (Komarevtseva, 2017). This drawback stems from the lack of regulatory framework and the smart city design tools for municipal economy. The problem that has arisen is based on insufficient introduction of digital technologies into municipal economy (Hämäläinen, 2020).

Today the smart city concept is considered as a theoretical tool for the development of territo- 
ries. Research within the framework of the smart city concept includes areas for the development of smart cities, technologies for modernizing the environment, the conceptual apparatus, on-line model of city management, stages of implementing the smart city concept and so on. In Russian practice, the smart city concept is not adapted to municipal economy. The lack of an adequate methodology for assessing the implementation of technologies in municipalities impedes "smart development" of small territories. This factor determines the relevance of the topic of this study.

\section{Method and Data}

In our study we are going to build a simulation model of municipal economy by applying the method of simulation modeling (Min et al., 2015) and the Bass diffusion model (Svítek et al., 2020).

To assess and build the simulation model of the feasibility of introducing smart city technologies in a municipality, we used statistical data from the report of socio-economic development of the city of Orel in 2017-2019. The indicators used in the report make it possible to form a relevant system for aligning the key aspects of the smart city concept with the main areas of the municipality's development.

\section{Results}

The smart city concept centres around the idea of improving the quality of life in a city with the help of innovative (or smart) technologies. In this light, areas of the urban environment include smart management, smart technology, smart environment, smart ecology, smart infrastructure, smart finance, and smart economy. Importantly, active engagement of urban dwellers into their cities' economic development is ensured with the help of digital technologies.

The main problem that makes the research of smart city development in Russian municipalities difficult is the large amount of parametric data that need to be processed. This problem can be solved with the help of indicators of feasibility of smart city projects in Russian municipalities. Table 1 highlights the indicators of the smart city concept that can be used for assessing municipal economy.

As we have pointed out above, the current system of indicators used for smart city evaluation has a number of drawbacks. Firstly, there is no calculation of the final result and it is impossible to draw a conclusion about the development of municipal economy. Secondly, the key areas include too many indicators. Thirdly, the statistical data necessary for evaluation are not always available. Thus, it can be concluded that the system of indicators of the smart city concept is not adequate to the reality of Russian municipalities and statistical services. All of the above has led us to propose a modified smart city concept for more effective development of municipal economy in Russia.

The proposed indicators for evaluating smart city development include the following:

1. innovative diversity $\left(I_{S C}\right)$ :

$$
I_{S C}=\frac{P \cdot p_{n}}{C_{e} \cdot C_{i}}-\frac{G}{I_{n}}
$$

where $I_{S C}$ is the criterion for innovative diversity; $P$ is the volume of shipped innovative products, goods and services (million rubles); $p_{n}$ is the research and innovative potential of the municipality; $C_{e}$ is the costs of technological moderni-

Table 1

\section{Evaluation indicators of the modified smart city concept for municipal economy}

\begin{tabular}{|l|l|l|}
\hline \multicolumn{1}{|c|}{ Area } & \multicolumn{1}{|c|}{ Evaluation indicators } & \multicolumn{1}{|c|}{ Indicator description } \\
\hline Smart economy & $\begin{array}{l}\text { The level of the development of R\&D, on-line booking system, and com- } \\
\text { munication technologies }\end{array}$ & innovative diversity $\left(I_{S C}\right)$ \\
\hline Smart management & $\begin{array}{l}\text { The level of informatization, openness of the city government, document } \\
\text { circulation and strategic planning }\end{array}$ & $\begin{array}{l}\text { information interaction of } \\
\text { management agents }\left(U_{S C}\right)\end{array}$ \\
\hline Smart population & The level of accessibility of the labor market, activity of Internet users & $\begin{array}{l}\text { intellectualization of the } \\
\text { population }\left(N_{S C}\right)\end{array}$ \\
\hline Smart technology & $\begin{array}{l}\text { The level of development of uninterrupted access networks, telemetry, } \\
\text { free wireless access in transport }\end{array}$ & digital support $\left(T_{S C}\right)$ \\
\hline Smart environment & Elimination of landfills, monitoring of environmental safety & ecological safety $\left(E_{S C}\right)$ \\
\hline Smart infrastructure & $\begin{array}{l}\text { The level of development of car sharing public transport, network of fil- } \\
\text { ling stations for electric vehicles, information systems in urban planning }\end{array}$ & online media $\left(F_{S C}\right)$ \\
\hline Smart finance & $\begin{array}{l}\text { The level of transparency in government procurement practices, the } \\
\text { level of investment in the city's economy }\end{array}$ & financial security $\left(S_{S C}\right)$ \\
\hline
\end{tabular}

Source: Komarevtseva, 2017; Merlino, Bruneo, Long, Puliafito, Distefano, 2015 
zation (million rubles); $C_{i}$ is costs of introducing information systems into the economy of the municipality (million rubles); $G$ is the amount of grants received by scientific and educational organizations of the municipality in the current year (million rubles); $I_{n}$ is the total cost of intellectual property products registered on the territory of the municipality (million rubles).

2. information interaction of management agents $\left(U_{S C}\right)$ :

$$
U_{S C}=\left(\frac{I_{i}}{I_{k-1}}\right) \cdot u_{i}-\left(\frac{I_{u}}{I_{u-1}}\right) \cdot u_{o},
$$

where $U_{S C}$ is the criterion of information interaction of management agents; $I_{k}$ is the number of citizens' initiatives registered through requests to local governments in the current year; $I_{k-1}$ is the number of citizens' initiatives registered through requests to local governments in the previous year; $u_{i}$ is the level of development of information systems of the municipal administration; $I_{u}$ is the number of satisfied applications of citizens of the municipality, out of the number registered in the current year; $I_{u-1}$ is the number of satisfied applications of citizens of the municipality, from the number registered in the previous year; $u_{o}$ is the level of information transparency of municipal government.

3. intellectualization of the population $\left(N_{S C}\right)$ :

$$
N_{S C}=\left(\frac{K_{i}}{K_{b}}\right) \cdot u_{d}-\left(\frac{K_{n}}{K_{a}}\right) \cdot u_{a},
$$

where $N_{S C}$ is the criterion of intellectualization of the population; $K_{i}$ is the number of jobs in the innovation sector of municipal economy; $K_{b}$ is the number of unemployed people in the municipality; $u_{d}$ is the level of accessibility of labor market data; $K_{n}$ is the number of people working in research and education; $K_{a}$ is the economically active population; $u_{a}$ is the level of activity of Internet users of the municipality.

4. digital support area $\left(T_{S C}\right)$ :

$$
T_{S C}=\left(Z_{u} \cdot Z_{g}\right)-\left(k_{i} \cdot i_{e}\right),
$$

where $T_{S C}$ is the digital support area; $Z_{u}$ is the level of use of digital technologies in people's daily life; $Z_{g}$ is the level of digital literacy of the population; $k_{i}^{g}$ is the coefficient of infrastructural accessibility of digital technologies; $i_{e}$ is the indicator of the effectiveness of digital technologies for municipal economy.

5. ecological safety $\left(E_{S C}\right)$ :

$$
E_{S C}=\left(p_{e} \cdot k_{p}\right)-\left(p_{n} \cdot k_{v}\right)
$$

where $E_{S C}$ is the criterion of ecological safety; $p_{e}$ is the rate of environmental pollution of the territory; $k_{p}$ is the coefficient of economic peril; $p_{n}$ is the indicator of excess of standards for the level of waste; $k_{v}$ is the coefficient of harmful environmental impact of the municipality's industrial enterprises.

6. online media $\left(F_{S C}\right)$ :

$$
F_{S C}=S_{o}-S_{n} \text {, }
$$

where $F_{S C}$ is the criteria for online media; $S_{o}$ is the amount of transactions made online (within the framework of infrastructure and transport services) (million rubles); $S_{n}$ is the amount of cash transactions (within the framework of infrastructure and transport services) (million rubles).

7. financial security $\left(S_{S C}\right)$ :

$$
S_{S C}=\frac{D+F}{R+M+K}-\frac{Z \cdot u_{r}}{B},
$$

where $S_{S C}$ is the criterion of financial security; $D$ is the indicator of budget revenues of the municipality (million rubles); $F$ is the financial performance of enterprises located on the territory (million rubles); $R$ is the budget expenditures of the municipality (million rubles); $M$ is the municipal debt (million rubles); $K$ is the accounts payable of enterprises located on the territory of the municipality (million rubles); $Z$ is the amount of public funds saved through public procurement (million rubles); $B$ is the amount of non-cash transfers within the framework of social and economic services for the population (million rubles); $u_{r}$ is the level of development of the banking system.

The indicators reflect the specific focus of the modified smart city concept for municipal economy. For smart economy the focus is innovative diversity; for smart management, information interaction of management agents; for smart population, intellectualization; for smart technology, digital support for smart environment, ecological safety; for smart infrastructure, online media; and for smart finance, financial security. To evaluate smart city development according to the proposed criteria, we need to whether the results for each criterion are positive or negative: a positive result means that this aspect of the smart city concept is being successfully implemented in the given city while a negative result means the opposite.

The following table contains the resulting criterion values for the city of Orel (Table 2). 
Table 2

Evaluation of smart city development in Orel

\begin{tabular}{|c|c|c|c|c|c|c|c|}
\hline Year & $\boldsymbol{I}_{S C}$ & $\boldsymbol{U}_{S C}$ & $\boldsymbol{N}_{S C}$ & $\boldsymbol{T}_{S C}$ & $\boldsymbol{E}_{S C}$ & $\boldsymbol{F}_{S C}$ & $\boldsymbol{S}_{S C}$ \\
\hline 2017 & -1.60 & -1.42 & -1.86 & -0.18 & -2.42 & 1.32 & -0.90 \\
\hline 2018 & -0.84 & -1.25 & -1.58 & -0.82 & -3.24 & 3.42 & -0.88 \\
\hline 2019 & -0.15 & -1.20 & -1.42 & -0.90 & -4.01 & 4.15 & -0.82 \\
\hline
\end{tabular}

Source: the authors' calculations used statistical indicators of socio-economic development of the city of Orel in 20172019 and formulae (1)-(6)

In 2017-2019, smart city development in Orel brought certain results. In this study, we are going to forecast the development of economy in Orel for the period of 2019-2025. We will build a simulation model of the functioning of the municipal economy within the framework of the modified smart city concept. For simulation modelling we applied AnyLogic software. The method of imitation is the Bass diffusion. The simulation model is expected to show whether the economy of Orel will develop within the smart city concept until 2025.

At the initial stage, we check the resulting indicator values for the smart city concept.

The simulation model of the modified smart city concept in Orel is formulated the following way. Different aspects of the concept are aligned with specific 'drives' ('drive' here is understood as a system of variables and dynamic processes accumulated within one area of the smart city concept). The category 'drive' is used in the simulation modelling program AnyLogic. For example, the drive 'Orel' corresponds to the municipality of Orel; 'economy', to smart economy; 'management', to management; 'technology', to smart technologies; 'ecology', to smart environment; 'information', to smart infrastructure; and 'finance', to 'smart finance'. Dynamic variables enable us to make predictions based on the given parameters and the cyclical tuning of the municipal economy. The designation of dynamic variables is based on the criterion value.

For example, the criterion for innovative diversity is identical to $I_{S C}$. The simulation model parameters are value-based. The model values reflect the final result of the dynamic variables. For example, for the criterion of innovative diversity, the set of variables include $P$ as the volume of shipped innovative products, goods and services; $p_{n}$ the research and innovative potential of the municipality; $C_{e}$, the costs of re-equipping the economy towards technological equipment; $C_{i}$, the costs of introducing information systems into the economy of the municipality; $G$, the amount of grants received by research and educational organizations of the municipality in the current year; $I_{n}$, the total cost of intellectual property products registered on the territory of the municipality.

Verification of the model's accuracy involves simulation assessment of the feasibility of smart city technologies in the 'smart economy' of Orel. The drive is 'economy' with the given dynamic variable and parameter values for 2019. In accordance with Table 2, the final result of the indicator in 'smart economy' of Orel was -0.15 in 2019. This condition should be met in the simulation model.

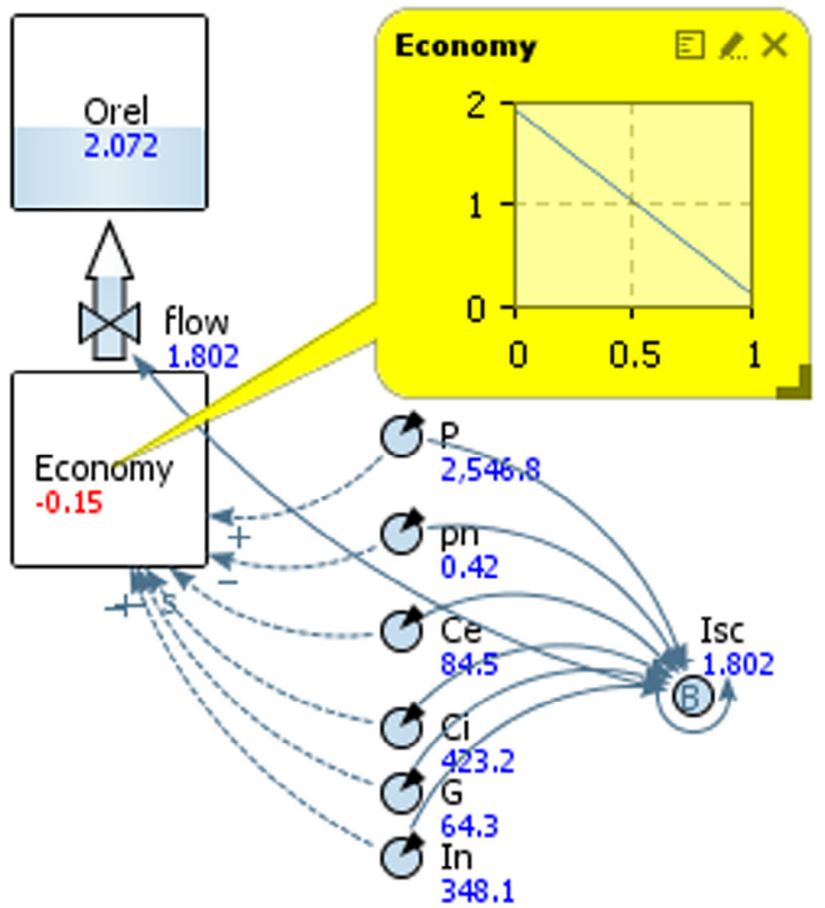

Figure 1. Simulation of the modified smart city concept implementation in Orel

Source: the authors' calculations used statistical indicators of socio-economic development of the city of Orel in 2017-2019 and AnyLogic program

The purpose of simulation modeling is to build a modified smart city model for studying the municipal economy of Orel with a predictive function until 2025. To this end, it is necessary to identify the priority areas of economic development to be included in the model. To simulate the model, we will form the estimated accumulators with the given dynamic variables and parameters of the economy of Orel. The forecasting lag is up to 2025. The limitations of the simulation model include the risk components from changes in the external environment and the transformations in the legislation in the field of the digital economy. These restrictions are determined by the level of 
cyclicity of dynamic variables. The final model for the economy of Orel is presented in Figure 2 below.

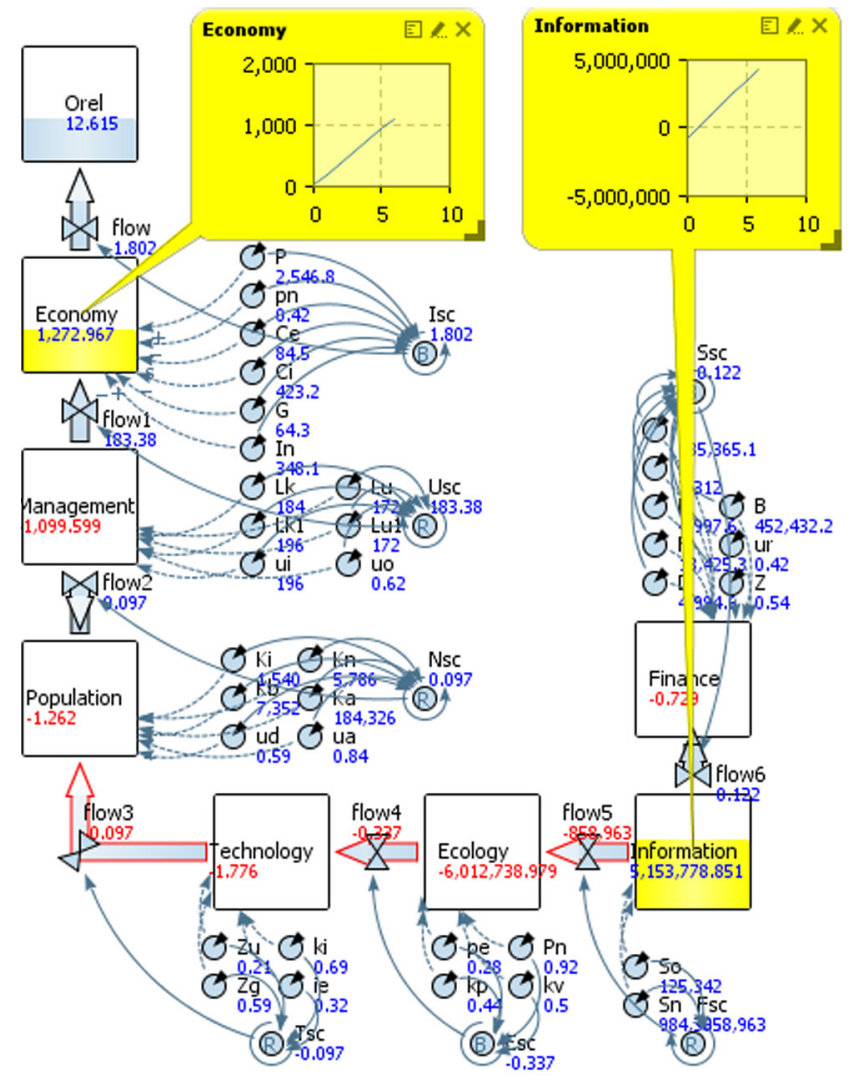

Figure 2. The smart city model modified for the economy of Orel municipality

Source: the authors' calculations used statistical indicators of socio-economic development of the city of Orel in 2017-2019 and AnyLogic program

The smart city model modified for Orel municipality shows positive dynamics and good prospects of smart infrastructure development for the period until 2025. The proposed modified smart city concept turned to be applicable for this city's economy. The model's important feature is the allocation of negative results for different spheres of the city's economy.

According to the forecasted values for 2025, we expect negative dynamics for the indicators. The areas that cause most concern are the technological development and environment. The problems in these areas may be solved with the help of special software products.

\section{Conclusion} sions:

Our research has led to the following conclu-

1. The smart city concept hasn't been tested for the current state of most municipal economies in Russia. The main disadvantages of the existing concept of smart city include the following: insufficient assessment of the final results of the concept's implementation in municipal economy, excess of indicators in the evaluation system of smart city development, and the lack of access to reliable statistical data.

2. To address the above-described shortcomings, we created a simplified smart city concept for studying municipal economy. This concept includes nine areas assessed on the basis of the following criteria: innovative diversity, information iteraction of management agents, intellectualization of the population, digital support area, ecological safety, online media, and financial security.

3. The simulation model can be used for forecasting the development of a municipality, for example, such forecasting was conducted for the city of Orel until 2025. It should be noted that of all areas of municipal development, the development of smart economy and smart infrastructure are of prime importance.

\section{References}

Anthopoulos, L., Janssen, M., \& Weerakkody, V. (2016). A unified Smart City model (USCM) for Smart City conceptualization and benchmarking. International Journal of Electronic Government Research, 2, 77-93. doi: 10.4018/IJEGR.2016040105.

Barriga, J.K.D., Romero, C.D.G., \& Molano, J.I.R. (2016). Proposal of a standard architecture of IOT for Smart Cities. Communications in Computer and Information Science, 620, 77-89. doi: 10.1007/978-3-319-42147-6 7.

Cao, X.-H., \& Wang, F.-Z. (2011). Research on e-commerce platform and modern logistics management system based on knowledge management platform. Applied Mechanics and Materials, 50-51, 145-149. doi: 10.4028/www.scientific.net/AMM.50-51.145.

Chan, C.S., Peters, M., \& Pikkemaat, B. (2019). Investigating visitors' perception of Smart City dimensions for city branding in Hong Kong. International Journal of Tourism Cities, 4, 620-638. doi: 10.1108/IJTC-07-2019-0101.

De Domenico, M., Arenas, A., Lima, A., \& González, M.C. (2015). Personalized routing for multitudes in Smart cities. EPJ Data Science, 1, 1-11. doi: 10.1140/epjds/s13688-015-0038-0. 
Glebova, I.S., Yasnitskaya, Y.S., \& Maklakova, N.V. (2014). Possibilities of 'Smart city' concept implementing: Russia's cities practice. Mediterranean J. of Social Sciences, 12, 129-133.

Habib, A., Prybutok, V.R., \& Alsmadi, D. (2020). Factors that determine residents' acceptance of Smart City technologies. Behaviour and Information Technology, 6, 610-623. doi: 10.1080/0144929X.2019.1693629.

Hämäläinen, M. (2020). A framework for a Smart City design: digital transformation in the Helsinki Smart City. Contributions to Management Science, 63-86. doi: 10.1007/978-3-030-23604-5 5.

Horejsi, P., Novikov, K., \& Simon, M. (2020). A smart factory in a Smart City: virtual and augmented reality in a Smart assembly line. IEEE Access, 8, 94330-94340. doi: 10.1109/ACCESS.2020.2994650.

Ishkineeva, G., Ishkineeva, F., \& Akhmetova, S. (2015). Major approaches towards understanding smart cities concept. Asian Social Science, 5, 70-73. doi: 10.5539/ass.v11n5p70.

Junior, S., Silvestre, B., Oliveira-Jr, A., Borges, V., Riker, A., \& Moreira, W. (2020). Dynasti-dynamic multiple RPL instances for multiple IOT applications in Smart City. Sensors, 11, 3130. doi: 10.3390/s20113130.

Khatoun, R., \& Zeadally, S. (2016). Smart cities: concepts, architectures, research, opportunities. Association for Computing Machinery. Communications of the ACM, 8, 46-57. doi: 10.1007/978-3319-23440-3 7 .

Komarevtseva, O.O. (2017). Simulation of data for determining the readiness of municipalities to implement smart city technologies. In: CEUR Workshop Proceedings, Moscow, 129-135. doi: 10.1155/2014/867593.

Medvedev, A., Fedchenkov, P., Zaslavsky, A., Anagnostopoulos, T., \& Khoruzhnikov, S. (2015). Waste management as an IOT-Enabled service in smart cities. Lecture Notes in Computer Science, 9247, 104-115. doi: 10.1007/978-3-319-23126-6 10.

Merlino, G., Bruneo, D., Longo, F., Puliafito, A., \& Distefano, S. (2015) Software defined cities: a novel paradigm for smart cities through IOT clouds. $12^{\text {th }}$ IEEE Int. Conf. on Ubiquitous Intelligence and Computing, 909-916.

Min, W., Bao, B.-K., Xu, C., \& Hossain, M.S. (2015). Cross-platform multi-modal topic modelling for personalized inter-planform recommendation. IEEE Transactions on Multimedia, 17, 1787-1801. doi: 10.1007/s11042-016-4039-1.

Scornavacca, E., Paolone, F., Martiniello, L., \& Za, S. (2020). Investigating the Entrepreneurial perspective in Smart City studies. The International Entrepreneurship and Management Journal, 16, 1197-1223. doi: $10.1007 /$ s11365-019-00630-4.

Svítek, M., Skobelev, P.O., \& Kozhevnikov, S. (2020). Smart City 5.0 as an urban ecosystem of Smart services. Studies in Computational Intelligence, 853, 426-438. doi: 10.1007/978-3-030-27477-1 33.

Tan, S.Y., \& Taeihagh, A. (2020). Smart City governance in developing countries: a systematic literature review. Sustainability, 3, 899. doi: 10.3390/su12030899.

Zhuhadar, L., Thrasher, E., Marklin, S., \& de Pablos P.O. (2017). The next wave of innovation review of smart cities intelligent operation systems. Computers in Human Behavior, 66, 273-281. doi: 10.1016/j.chb.2016.09.030.

\section{Information about the author}

Olga O. Komarevtseva - Post-graduate Student of the Department of National and Regional Economics of the Plekhanov Russian University of Economics (Stremyanny lane, 36, Moscow, 117997, Russia), e-mail: komare_91@mail.ru.

ARTICLE INFO: received October 9, 2020; accepted December 8, 2020

\section{Информация об авторе}

Комаревцева Ольга Олеговна - соискатель кафедры национальной и региональной экономики, Российский экономический университет им. Г.В. Плеханова (117997, Российская Федерация, г. Москва, Стремянный пер., 36), e-mail: komare_91@mail.ru.

ИНФОРМАЦИЯ О СТАТЬЕ: дата поступления 9 октября 2020 г.; дата принятия к печати 8 декабря 2020 г. 